Sains Malaysiana 49(6)(2020): 1411-1420

http://dx.doi.org/10.17576/jsm-2020-4906-19

\title{
Bone Density and Marginal Bone Loss Around Implants Post Ultraviolet A and Ultraviolet C Irradiation
}

(Ketumpatan Tulang dan Kehilangan Tulang Tepi yang Mengelilingi Implan Pasca Iradiasi Ultralembayung A dan Ultralembayung C)

\author{
NaAuman Zaheer, Zainul Ahmad bin Rajion*, Maliha Shahbaz, Usman Zaheer, Muhammad Qasim \\ SAEED \& NOOR HAYATI ABDUl RAZAK
}

\begin{abstract}
The aim of this paper was to evaluate marginal bone loss (MBL) and bone density (BD) in the alveolar bone surrounding the titanium implants with or without ultraviolet (UV) pre-treatment at different wavelengths in vivo. Randomized control trial conducted at the CMH Lahore Medical College, Institute of Dentistry. This interventional study enrolled patients undergoing replacement of missing teeth. Sixty-six Dio UFII implants with hybrid sandblasted and acidetched (SLA) surface treatments were divided equally into three groups. Control Group A was not irradiated, while implants in groups $B$ and C were irradiated with UVA $\left(382 \mathrm{~nm}, 25 \mathrm{mWcm}^{2}\right)$ and $U V C\left(260 \mathrm{~nm}, 15 \mathrm{mWcm}^{2}\right)$, respectively. MBL and BD in the surrounding bone were evaluated at day 0 (baseline) and 8th and 26th week. SPSS 20.0 was used for data analysis. Repeated measure ANOVA followed by One-way ANOVA, Tukey's test and Paired t-test were used for comparison. $p \leq 0.05$ was considered statistically significant. Both UVA and UVC treated groups showed minimal MBL compared to control group, with no significant difference between the two experimental groups. Meanwhile, there was a steady increase in $B D$ in all groups over time, with UVC showing a significant improvement between the 8th and 26th week. MBL was reduced and BD was increased in both UV treated groups. However, UVC irradiation has the potential to control MBL and produce denser bone in SLA coated implants.
\end{abstract}

Keywords: Bone density; cone beam computed tomography; marginal bone loss; photofunctionalization

\section{ABSTRAK}

Kajian ini dijalankan untuk menilai kehilangan tulang tepi (MBL) dan ketumpatan tulang (BD) dalam tulang alveolar yang mengelilingi implan titanium dengan atau tanpa rawatan awal ultralembayung (UV) pada jarak gelombang berbeza secara in vivo. Percubaan rawak terkawal dijalankan di Kolej Perubatan CMH Lahore, Institut Pergigian. Pesakit kajian intervensi ini dipilih menjalani penggantian gigi. Enam puluh enam implan Dio UFII dengan permukaan rawatan dibuat penyemburan pasir hibrid dan beretsa asid (SLA) dibahagikan sekata kepada tiga kumpulan. Kumpulan Kawalan A tidak diiradiasi, implan kumpulan B dan C diiradiasi dengan UVA $(382 \mathrm{~nm}, 25 \mathrm{mWcm}$ ) dan UVC (260 nm, $15 \mathrm{mWcm}{ }^{2}$ ). Mbl dan BD di sekeliling tulang dinilai pada hari 0 (garis dasar) dan minggu ke-8 dan ke26. SPSS 20.0 digunakan untuk analisis data. ANOVA ukuran berulang dilakukan diikuti ujian One-way ANOVA, ujian Tukey dan t-test berpasangan digunakan untuk perbandingan. $p \leq 0.05$ dianggap sebagai signifikan secara statistik. Kedua-dua kumpulan UVA dan UVC menunjukkan MBL yang minimal berbanding dengan kumpulan kawalan, dengan tiada perbezaan signifikan antara kedua-dua kumpulan uji kaji tersebut. Walau bagaimanapun, terdapat peningkatan tetap dalam BD pada kesemua kumpulan berkadar dengan masa, dengan UVC menunjukkan peningkatan signifikan antara minggu ke-8 dan minggu ke-26. MBL dikurangkan dan BD ditingkatkan dalam kedua-dua kumpulan yang dirawat dengan UV. Walau bagaimanapun, iradiasi UVC mempunyai potensi untuk mengawal MBL dan menghasilkan tulang yang lebih padat dalam implan yang disaduri SLA.

Kata kunci: Kehilangan tulang tepi; kepadatan tulang; pemfungsian cahaya; tomografi berkomputer cahaya kon

\section{INTRODUCTION}

Bone loss and remodeling is inevitable after tooth extraction and particularly after implant placement and loading. However, the amount of bone loss varies in different cases (Schropp \& Wenzel 2016). During the first year, $1.5 \mathrm{~mm}$ of marginal bone resorption and $0.2 \mathrm{~mm}$ annually during subsequent years is considered acceptable (Albrektsson et al. 2014). Marginal bone loss (MBL) is 
considered as a sensitive tool for evaluation of success of implant because a pathological loss of bone might lead to implant failure. The exact etiology of marginal bone loss is unknown but the following factors such as trauma, bacterial infection, biomechanical overload, micro gap existing between the fixture and abutment play a pivotal role in bone loss (Koller et al. 2016)

Bone density reflects the strength of the bones as represented by its calcium content. The ultraviolet irradiation of titanium dental implants; known as photofunctionalization; causes certain physiochemical and biological changes on implant surface which enhances bone formation during early phases of osseointegration (Mehl et al. 2018). Animal studies concluded that bone-to-implant contact, including bone volume, have shown significant increase after UVA and UVC treatment of dental implants (Hirakawa et al. 2013; Pyo et al. 2013). However, another study concluded that UVC radiation significantly increases the bone volume compared to the non-irradiated implants, whereas there was no significant difference in bone density among the study groups (Yamazaki et al. 2015).

Thus, several studies have been done on photofunctionalized titanium implants evaluating different variables but radiographic assessment of marginal bone loss and bone density through $\mathrm{CBCT}$ with varying wavelength of ultraviolet radiation still needs to be done. Negligible human clinical trials have been done to assess the bone density around sandblasted acid-etched photofunctionalized titanium implants. In further studies, marginal bone loss and bone density of different surface modifications can be compared through CBCT.

This study aimed to give an insight of the role of photofunctionalized implants in delayed implant placement protocol where bone volume is already reduced, in hopes that further peri-implant marginal bone loss will be minimized.

\section{MATERIALS AND METHODS}

This randomized control trial was conducted at the CMH Lahore Medical College, Institute of Dentistry using Dio UFII hybrid sandblast acid-etched (SLA) dental implants, with approval from the local ethical committee of the $\mathrm{CMH}$ Lahore Medical College, Institute of Dentistry (32/ERC/CMH/LMC) and by the Human Research Ethics Committee USM (HREC) (USM/JEPem/17060290). All patients provided written, informed consent. Healthy individuals of both sexes aged $>20$ years who required implants to replace missing teeth after a healing period of at least 5 months were recruited and they were randomly allocated (block randomized) into three groups through lottery method (drawing cards).

\section{ULTRAVIOLET IRRADIATION}

$G$ Power software was used in order to determine the minimum sample size required for this analysis. The central and non-central distribution protocol of power analysis was selected along with F-test family. The ANOVA: Fixed effects, omnibus, one-way statistical test was used. The input had effect size $\mathrm{f}=0.4$, $\alpha$ err prob $=0.05$, Power $(1-\beta$ err prob $)=0.8$ in 3 number of groups. The out for noncentrality parameter $\lambda=10.5600000$, critical $\mathrm{F}=3.1428085$, numerator $\mathrm{df}=2$, denominator $\mathrm{df}=63$. A total of sixty-six sample size was obtained with actual power of 0.8180744 (Cohen 2013, 1992). Thus, sixtysix SLA-coated titanium dental implants (length, 8.5-13.0 $\mathrm{mm}$; width, 3.8-5.5 $\mathrm{mm}$ ) were selected for placing in the mandible or maxilla alveolar bone. Implants were also randomly divided into three groups $(\mathrm{n}=22)$ : Group A, control group, and groups $\mathrm{B}$ and $\mathrm{C}$, photofunctionalized for $10 \mathrm{~min}$ with UVA $\left(382 \mathrm{~nm}, 25 \mathrm{~mW} / \mathrm{cm}^{2}\right)$ and UVC $\left(260 \mathrm{~nm}, 15 \mathrm{~mW} / \mathrm{cm}^{2}\right)$ irradiation, respectively, by placing samples in UVACUBE 100 (Honle, Germany).

\section{SURGICAL PROCEDURE}

Cone beam computed tomography (CBCT) radiographs (Promax 3-D, Planmeca, version 4.6.4, Finland) were preoperatively obtained at the Jinnah MRI and body scan Centre, Lahore, Pakistan.

Following the surgical protocol for local anesthesia administration and full thickness flap reflection, implants were placed into the alveolar bone as recommended by the manufacturer (Maló et al. 2015, 2012). Each implant's neck was positioned at the bone level followed by healing abutment. Multiunit straight abutments or 15 or 25-degree angled abutments were used as appropriate to correct fixture inclination. The soft tissue was readapted and sutured.

CBCT radiographic assessment was again immediately obtained after placing the fixture to determine baseline and repeated during follow-up before ( 8 weeks) and after (26 weeks) functional loading. All recorded images were saved locally and transferred into the Romexis software.

\section{RADIOGRAPHIC ANALYSIS}

\section{Measurement of marginal bone loss (MBL)}

Peri-implant MBL was measured using $\mathrm{CBCT}$ at sagittal view in millimeters by drawing two perpendicular lines from the reference line at the maximum height of implant fixture to the first visible bone-to-implant contact (BIC) at the mesial and distal sides of the implant (Koller et al. 2016; Pour et al. 2015). Subsequently, bone loss of each individual was compared at the baseline: 8 and 26th week (Figure 1). 


\section{Measurement of bone density (BD)}

CBCT imaging detects the mineral content in the dense part of bone in Hounsfield units (HU). It is perceived that each voxel better represents gray value than HU; thus, phantoms of Acryl, aluminum, and inside oxygen in ProMax were scanned for calibration. The coefficient of variation of CBCT device is $8 \%$ ( Qu et al. 2010). The gray value of scanned phantoms can be converted to corresponding density values using a calibrated curve within the same CBCT scanner. Previous work has established this HU correction using phantoms as well (Kim 2014).

The bottom of the inner basic lamellae of the cortical bone at the maximum height of implant fixture was set as the baseline reference direction. To obtain control values of $\mathrm{BD}$, four regions of interest were established encompassing $1 \mathrm{~mm}^{2}$ within the existing cortical bone at least $1 \mathrm{~mm}$ away from the implant surface (Campos et al. 2012; Tatli \& Evlice 2017). BD was determined within the region of interest using the given $\mathrm{HU}$ value using CBCT (Figure 2).

\section{STATISTICAL ANALYSIS}

All statistical analyses were performed using SPSS 20.0. Data for MBL and BD were presented as mean \pm SD at baseline (day 0 ) and at 8 and 26 weeks for all the groups. Mixed design (Repeated measure) ANOVA was used to see the difference among groups and within three reading times by using Greenhouse-Geisser method. Marginal estimated means for three measures were presented by using line graphs and later for comparison among groups for three measures one-way ANOVA at each reading time. The Tukey's test was used as a post hoc test to determine where differences lie. Paired $t$-test was used to compare all three measures among three reading times for each group separately. A p-value of $\leq$ 0.05 was considered statistically significant.

\section{RESULTS}

Sixty-six cases included in study had an average age of $40.6 \pm 12.1$ years and 24 of them were males. The average age of control group was $40.4 \pm 12.9$ while for
UVA it was $42.9 \pm 11.4$ and for UVC it was $38.5 \pm 12$. The number of male patients for three groups were 6,9 , and 9 , respectively.

The initial comparison by repeated measure ANOVA presented time as a highly significant factor playing the role in changes of three measures (mean bone loss at mesial and distal, bone density). It was also noted that the time and group interaction was also significant, which suggested that the further analysis between groups and within time for each group are required (Table 1).

The mean bone loss at week 8 on both mesial and distal sides of the implant was significantly low in both the UV groups compared with the control. However, the difference between the UVA and UVC groups was insignificant. Similar results were observed on the mesial and distal sides of implants at week 26 . The bone density when compared between three groups at each reading time had no significant difference at all (Table 2).

While making comparison between times, it was observed that the mean bone loss at mesial was significantly increased till 8 weeks as well as between 8 week and 26 weeks in control group, so were the changes for distal as well. The bone density increased significantly till 8 th week with $p$-value $\leq 0.001$ but then the change was insignificant for this group. When same comparisons were made for the group treated with UVA the change of bone loss at mesial as well as distal were noted insignificant till 8th week with p-values 0.096 and 0.186 , respectively. Changes noted onward for both measures were highly significant with $\mathrm{p}$-value $\leq 0.001$. The bone density in this group increased significantly at 8th and 26th week compared to baseline but the change between 8 week and 26 weeks was insignificant with p-value 0.226 . Finally, the comparisons for group treated with UVC were also made and it was observed that the changes in mean bone loss were insignificant at mesial as well as distal between baseline and 8 weeks. The bone loss at distal remained unchanged between 8 th and 26th week but for mesial the change of 26th week compared to baseline and 8th week was significant with p-values 0.005 and 0.045 , respectively. The bone density increased significantly between three times, all with p-values $\leq$ 0.001 (Table 3, Figure 3).

TABLE 1. Comparison of measures among three groups at three reading times overall by using Repeated Measure ANOVA (Greenhouse-Geisser method)

\begin{tabular}{|c|c|c|c|c|c|c|}
\hline Measure & Source & $\begin{array}{l}\text { Type III Sum } \\
\text { of Squares }\end{array}$ & $\mathrm{df}$ & $\begin{array}{l}\text { Mean } \\
\text { Square }\end{array}$ & $\mathrm{F}$ & p-value \\
\hline \multirow{3}{*}{$\begin{array}{l}\text { Mean Bone loss_Mesial } \\
(\mathrm{mm})\end{array}$} & Time & 1.988 & 1.708 & 1.164 & 39.022 & $<0.001 * *$ \\
\hline & Time * Groups & 1.575 & 3.415 & 0.461 & 15.456 & $<0.001 * *$ \\
\hline & Error (Time) & 3.210 & 107.579 & 0.030 & & \\
\hline
\end{tabular}




\begin{tabular}{|c|c|c|c|c|c|c|}
\hline & Time & 3.884 & 1.466 & 2.650 & 59.417 & $<0.001^{* *}$ \\
\hline \multirow[t]{3}{*}{$\begin{array}{l}\text { Mean Bone loss_Distal } \\
(\mathrm{mm})\end{array}$} & Time * Groups & 4.328 & 2.931 & 1.477 & 33.104 & $<0.001 * *$ \\
\hline & Error (Time) & 4.118 & 92.331 & 0.045 & & \\
\hline & Time & 392208.82 & 1.06 & 368351.03 & 14.97 & $<0.001 * *$ \\
\hline \multirow[t]{2}{*}{ Bone Density $\left(\mathrm{mm}^{2}\right)$} & Time $*$ Groups & 4351.33 & 2.13 & 2043.32 & 0.08 & $0.930^{\mathrm{ns}}$ \\
\hline & Error (Time) & 1650390.52 & 67.08 & 24603.15 & & \\
\hline
\end{tabular}

** Significant at $\mathrm{p} \leq 0.05$, df: degrees of freedom

TABLE 2. Comparison of MBL and BD among three groups at each reading time (One Way ANOVA and Post Hoc Tukey's Test)

\begin{tabular}{|c|c|c|c|c|c|}
\hline \multirow{3}{*}{ Measure } & \multirow{3}{*}{$\begin{array}{c}\text { Time } \\
\text { (weeks) }\end{array}$} & \multicolumn{3}{|c|}{ Group } & \multirow{3}{*}{$\begin{array}{c}\text { p-value } \\
\text { By } \\
\text { ANOVA }\end{array}$} \\
\hline & & Control & UVA & UVC & \\
\hline & & Mean \pm SD & Mean \pm SD & Mean \pm SD & \\
\hline \multirow{2}{*}{$\begin{array}{l}\text { Mean bone loss mesial } \\
(\mathrm{mm})\end{array}$} & 8 & $0.23 \pm 0.43^{\mathrm{a}}$ & $0.02 \pm 0.06^{\mathrm{b}}$ & $0.01 \pm 0.04^{\mathrm{bc}}$ & $0.009 * *$ \\
\hline & 26 & $0.54 \pm 0.40^{\mathrm{a}}$ & $0.15 \pm 0.13^{b}$ & $0.03 \pm 0.05^{\mathrm{bc}}$ & $<0.001 * *$ \\
\hline \multirow{2}{*}{$\begin{array}{l}\text { Mean bone loss distal } \\
(\mathrm{mm})\end{array}$} & 8 & $0.43 \pm 0.54^{\mathrm{a}}$ & $0.01 \pm 0.05^{\mathrm{b}}$ & $0.01 \pm 0.05^{\mathrm{bc}}$ & $<0.001 * *$ \\
\hline & 26 & $0.85 \pm 0.41^{\mathrm{a}}$ & $0.16 \pm 0.17^{b}$ & $0.02 \pm 0.06^{\mathrm{bc}}$ & $<0.001 * *$ \\
\hline \multirow{3}{*}{ Bone density } & 0 & $633 \pm 277$ & $614 \pm 161$ & $512 \pm 171$ & $0.128^{\mathrm{NS}}$ \\
\hline & 8 & $682 \pm 304$ & $670 \pm 180$ & $551 \pm 178$ & $0.118^{\mathrm{NS}}$ \\
\hline & 26 & $739 \pm 310$ & $720 \pm 187$ & $627 \pm 218$ & $0.273^{\mathrm{NS}}$ \\
\hline
\end{tabular}

** Significant at $\mathrm{p} \leq 0.05$. Data are expressed as mean and SD $(\mathrm{n}=22)$. Common letter indicates insignificant difference assessed using Tukey's test. NS: non-significant, SD: standard deviation, ANOVA: analysis of variance, UVA: ultraviolet A, UVC: ultraviolet C 
TABLE 3. Comparison of three measures among three times for each group by using paired $t$-test

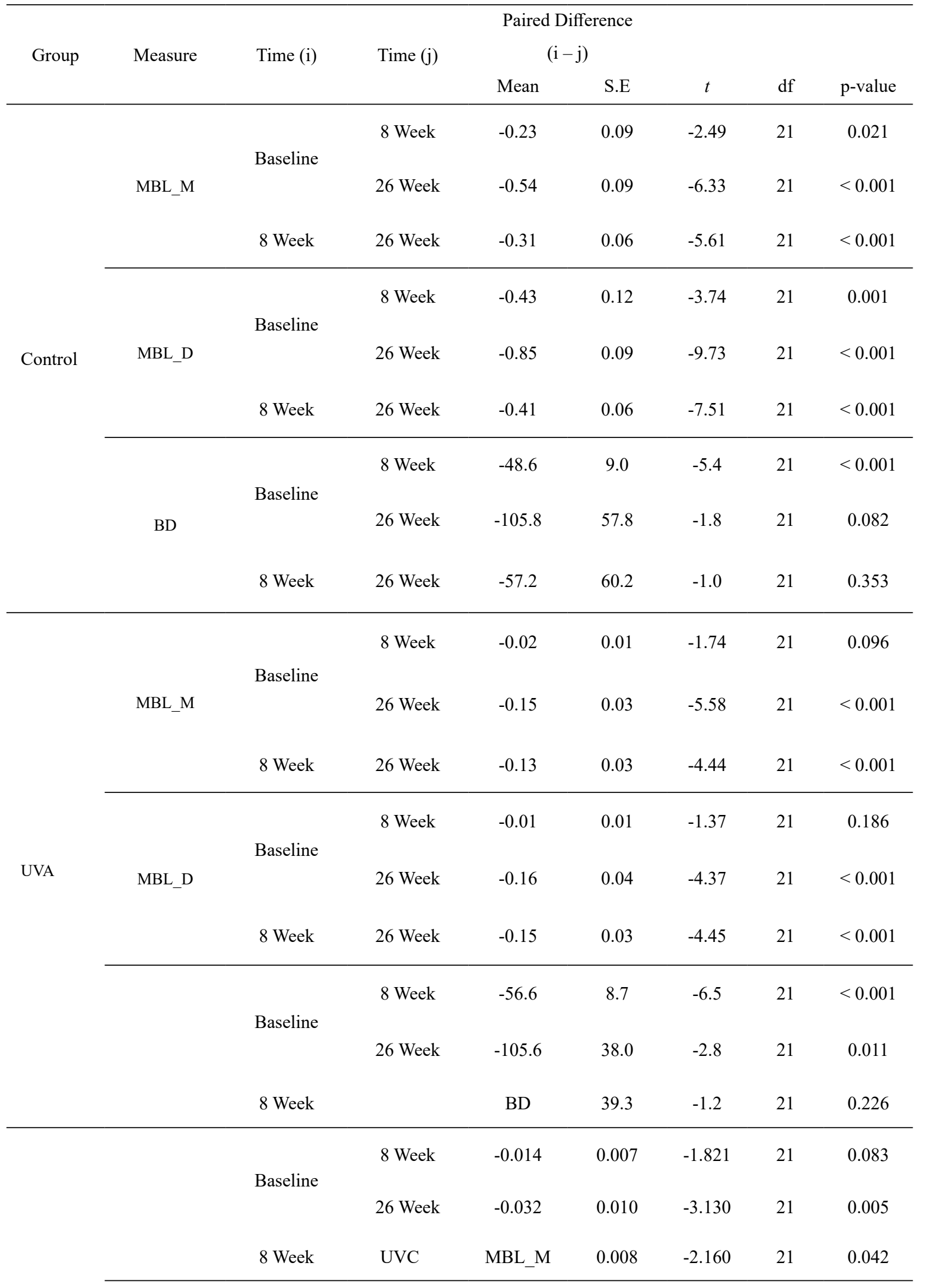




\begin{tabular}{|c|c|c|c|c|c|c|c|}
\hline & & 8 Week & -0.014 & 0.010 & -1.368 & 21 & 0.186 \\
\hline \multirow{3}{*}{ MBL_D } & Baseline & & & & & & \\
\hline & & 26 Week & -0.023 & 0.013 & -1.742 & 21 & 0.096 \\
\hline & 8 Week & 26 Week & -0.009 & 0.009 & -1.000 & 21 & 0.329 \\
\hline \multirow{4}{*}{$\mathrm{BD}$} & & 8 Week & -39.0 & 8.5 & -4.6 & 21 & $<0.001$ \\
\hline & Baseline & & & & & & \\
\hline & & 26 Week & -114.9 & 17.4 & -6.6 & 21 & $<0.001$ \\
\hline & 8 Week & 26 Week & -76.0 & 15.3 & -5.0 & 21 & $<0.001$ \\
\hline
\end{tabular}

*The mean difference is significant at $\mathrm{p} \leq 0.05$. The data are expressed as mean and $\mathrm{SD}(\mathrm{n}=22)$. df: degrees of freedom, $t$ : test statistics value for paired $\mathrm{t}$ test. SE: standard error for paired mean difference, UVA: ultraviolet A, UVC: ultraviolet C

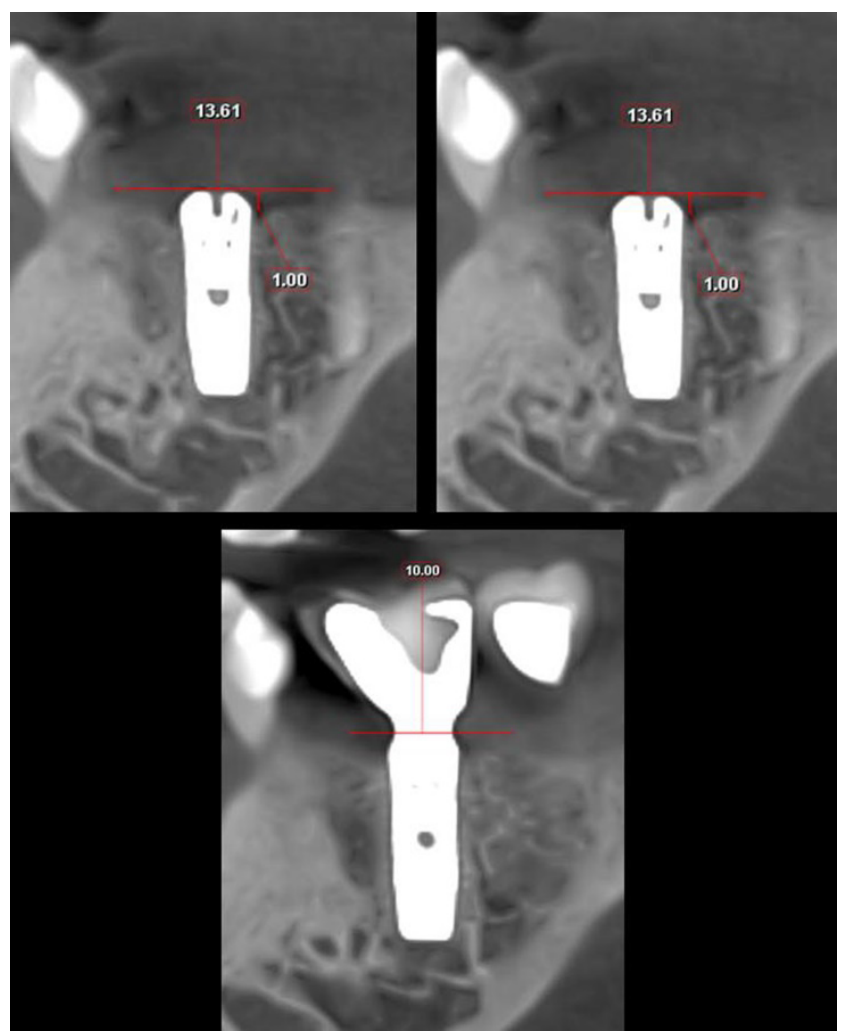

FIGURE 1. Marginal bone levels for UVC group on mesial and distal sides of the implant at day 0 (A), week 8 (B), and (C) week 26 of implant placement (Sagittal view, Romexis software) 


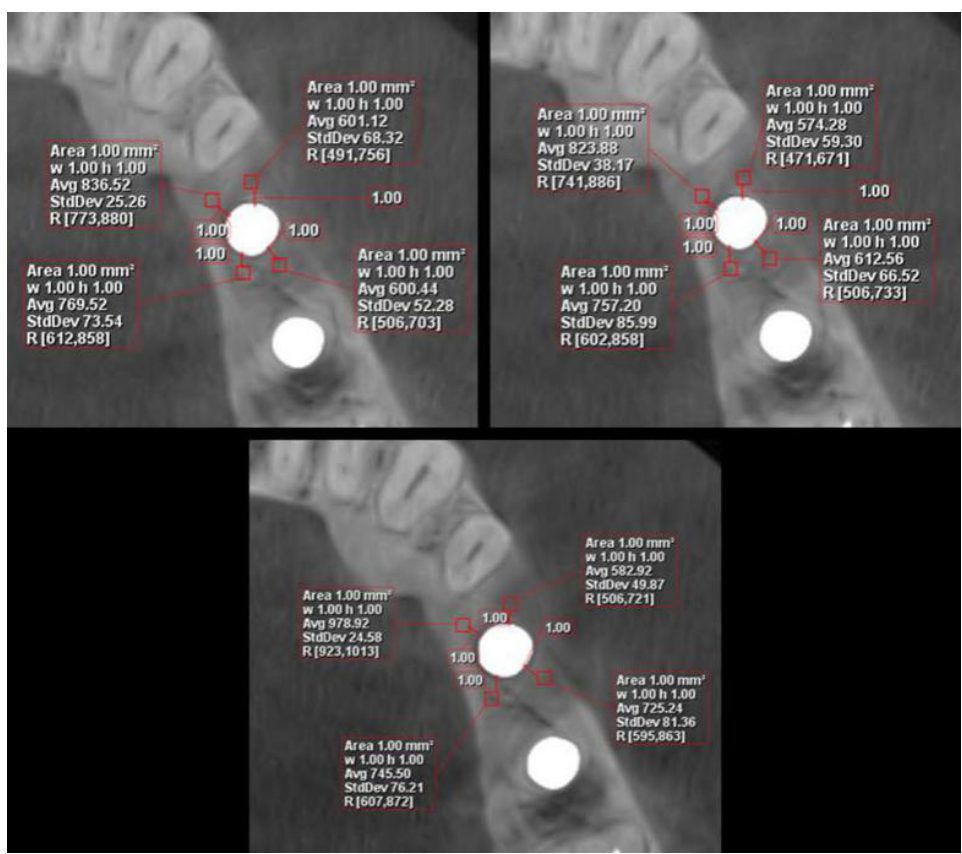

FIGURE 2. Axial view showing the region of interest of UVC group for measuring BD at day 0 (A), week 8 (B), and week 26 (C) (Romexis software)
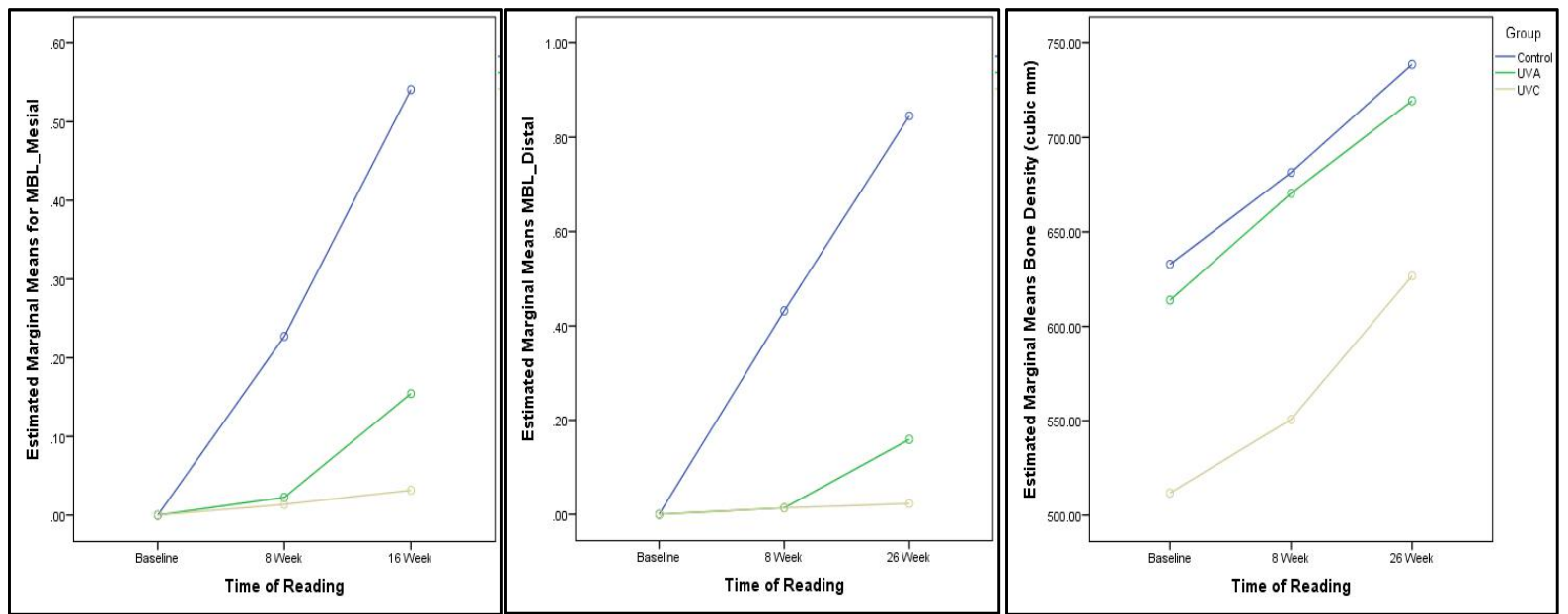

FIGURE 3. Marginal means for three measures over three reading times by line graphs 


\section{DISCUSSION}

Bone formation around an implant is the backbone of implant success. Therefore, evaluating MBL, BD, and soft tissue is a major part of the assessment protocol for implant patients (Boora et al. 2015). Implants lose their bioactivity after being manufactured (Flanagan 2016) and thus UV treatment can reduce ageing of the implant surface and minimize healing time for functional quick loading by initiating three dimensional bone growth (Elkhidir \& Cheng 2017). Over the years, numerous in vitro studies have been performed either using UVA or UVC each showing positive results regarding BIC (Flanagan 2016; Hirakawa et al. 2013). UV irradiation of titanium and zirconia implants has shown superiority to UVC radiation considering cellular proliferation and differentiation on implant surface (Aita et al. 2009; Al Qahtani et al. 2015). However, there is a lack of in vivo studies determining the optimal wavelength of UV radiation for implant success.

Photofunctionalized titanium dental implants placed in compromised fresh extraction sockets showed no MBL even after 1 year (Funato \& Ogawa 2013). In the present in vivo study with a shorter followup time of 3 months, there was a significant decrease in MBL on the mesial and distal side of implants in the UVA- and UVC-treated groups compared with that in the control group. Previously, studies showed promising results of UVC irradiation of different surface modifications of titanium and zirconia implants, which attracted more osteoblasts towards the implant surface in comparison to UVA (Al Qahtani et al. 2015). This may lead to more bone formation, thus reducing bone loss. Presently, although MBL difference in both the UV groups was minor, the UVC-treated group showed no bone loss on either side of the implant at the 26th week compared with the UVA-treated group.

Reportedly, greater volume and density of bone are critical for the successful outcomes of an implant (Cassetta et al. 2014). BD actually reflects the quantity of bone that helps in providing initial stability (Kim 2014). In the current study, UVC treatment led to a substantial increase in $\mathrm{BD}$ from 8th to 26th week, suggesting that UVC leads to better recruitment of osteoblasts to the implant surface for bone formation. This is likely because UVC promotes contact osteogenesis by enhancing the recruitment and attachment of osteogenic cells from the cortical bone, endosteum, and bone marrow and by the activation of interaction between those cells, leading to improved osseointegration (Uchiyama et al. 2014) regardless of the surface topography (Yamazaki et al. 2015). This cascade of events may lead to long-term success of an implant. Literature suggestive of marginal bone loss is a potential clinical sequence after implant placement and the findings of this study may highlight the alternative significant contribution of photofunctionalized implants. From the findings of the present study, SLA coated titanium photofunctionalized implants have shown substantial contribution to knowledge and science in implantology research area compared to non-treated group.

\section{CONCLUSION}

Photofunctionalized SLA-coated titanium dental implants showed positive biological response after healing phase in contrast to non-UV treated group. This provides an insight regarding the beneficial role of UV light exposure. Although the difference in MBL and BD was insignificant among the UV treated groups, radiographically, UVC showed better host response in terms of increased bone density as compared to UVA. However, complex response patterns still need to be compared among photofunctionalized implants with varying wavelengths on different surface modifications.

The sample size was low as there was no assistance or funding from government of Pakistan. The most challenging factor was time. Follow-up period of patients had to be maximum six months instead of one year.

\section{ACKNOWLEDGEMENTS}

We thank Universiti Sains Malaysia and CMH Lahore Medical College, Institute of Dentistry, for providing technical support on CBCT.

\section{REFERENCES}

Aita, H., Att, W., Ueno, T., Yamada, M., Hori, N., Iwasa, F., Tsukimura, N. \& Ogawa, T. 2009. Ultraviolet lightmediated photofunctionalization of titanium to promote human mesenchymal stem cell migration, attachment, proliferation and differentiation. Acta Biomaterialia 5(8): 3247-3257.

Al Qahtani, M.S., Wu, Y., Spintzyk, S., Krieg, P., Killinger, A., Schweizer, E., Stephan, I., Scheideler, L., Geis-Gerstorfer, J. \& Rupp, F. 2015. UV-A and UV-C light induced hydrophilization of dental implants. Dental Materials 31(8): e157-e167.

Albrektsson, T., Dahlin, C., Jemt, T., Sennerby, L., Turri, A. \& Wennerberg, A. 2014. Is marginal bone loss around oral implants the result of a provoked foreign body reaction? Clinical Implant Dentistry and Related Research 16(2): 155-165.

Boora, P., Rathee, M. \& Bhoria, M. 2015. Effect of platelet rich fibrin (PRF) on peri-implant soft tissue and crestal bone in one-stage implant placement: A randomized controlled trial. Journal of Clinical and Diagnostic Research: JCDR 9(4): 18-21. 
Cassetta, M., Stefanelli, L.V., Pacifici, A., Pacifici, L. \& Barbato, E. 2014. How accurate is CBCT in measuring bone density? A comparative CBCT-CT in vitro study. Clinical Implant Dentistry and Related Research 16(4): 471-478.

Cohen, J. 2013. Statistical Power Analysis for the Behavioral Sciences. London: Academic Press.

Cohen, J. 1992. Quantitative methods in psychology: A power primer. Psychological Bulletin 112: 1155-1159.

Flanagan, D. 2016. Photofunctionalization of dental implants. Journal of Oral Implantology 42(5): 445-450.

Funato, A. \& Ogawa, T. 2013. Photofunctionalized dental implants: A case series in compromised bone. International Journal of Oral \& Maxillofacial Implants 28(6): 15891601.

Elkhidir, Y.A.H. \& Cheng, Y. 2017. Achieving superosseointegration: The photofunctionalization effect. Dentistry 7(435): 2161-1122.

Hirakawa, Y., Jimbo, R., Shibata, Y., Watanabe, I., Wennerberg, A. \& Sawase, T. 2013. Accelerated bone formation on photoinduced hydrophilic titanium implants: An experimental study in the dog mandible. Clinical Oral Implants Research 24: 139-144.

Kim, D.G. 2014. Can dental cone beam computed tomography assess bone mineral density? Journal of Bone Metabolism 21(2): 117-126.

Koller, C.D., Pereira-Cenci, T. \& Boscato, N. 2016. Parameters associated with marginal bone loss around implant after prosthetic loading. Brazilian Dental Journal 27(3): 292-297.

Maló, P., de Araújo Nobre, M., Lopes, A., Ferro, A. \& Gravito, I. 2015. All-on-4® treatment concept for the rehabilitation of the completely edentulous mandible: A 7-year clinical and 5-year radiographic retrospective case series with risk assessment for implant failure and marginal bone level. Clinical Implant Dentistry and Related Research 17: e531-e541.

Maló, P., de Araújo Nobre, M., Lopes, A., Francischone, C. \& Rigolizzo, M. 2012. 'All-on-4' immediate-function concept for completely edentulous maxillae: A clinical report on the medium (3 years) and long-term (5 years) outcomes. Clinical Implant Dentistry and Related Research 14(Suppl 1): e139-e150.

Mehl, C., Kern, M., Neumann, F., Bähr, T., Wiltfang, J. \& Gassling, V. 2018. Effect of ultraviolet photofunctionalization of dental titanium implants on osseointegration. Journal of Zhejiang University-Science B 19(7): 525-534.

Pour, D.G., Romoozi, E. \& Shayesteh, Y.S. 2015. Accuracy of cone beam computed tomography for detection of bone loss. Journal of Dentistry (Tehran, Iran) 12(7): 513-523.

Pyo, S.W., Park, Y.B., Moon, H.S., Lee, J.H. \& Ogawa, T. 2013. Photofunctionalization enhances bone-implant contact, dynamics of interfacial osteogenesis, marginal bone seal, and removal torque value of implants: A dog jawbone study. Implant Dentistry 22(6): 666-675.

Qu, X.M., Li, G., Ludlow, J.B., Zhang, Z.Y. \& Ma, X.C. 2010. Effective radiation dose of ProMax 3D cone-beam computerized tomography scanner with different dental protocols. Oral Surgery, Oral Medicine, Oral Pathology, Oral Radiology, and Endodontology 110(6): 770-776.

Schropp, L. \& Wenzel, A. 2016. Timing of single implant placement and long-term observation of marginal bone levels. European Journal of Oral Implantology 9(Suppl 1): 107-122.

Tatli, U. \& Evlice, B. 2017. Cone-beam computed tomography for oral and maxillofacial imaging. Computed Tomography: Advanced Applications. https://doi.org/10.5772/ intechopen.69282.

Uchiyama, H., Yamada, M., Ishizaki, K. \& Sakurai, K. 2014. Specific ultraviolet-C irradiation energy for functionalization of titanium surface to increase osteoblastic cellular attachment. Journal of Biomaterials Applications 28(9): 1419-1429.

Yamazaki, M., Yamada, M., Ishizaki, K. \& Sakurai, K. 2015. Ultraviolet-C irradiation to titanium implants increases periimplant bone formation without impeding mineralization in a rabbit femur model. Acta Odontologica Scandinavica 73(4): 302-311

Naauman Zaheer

Oral Biology Department

Faculty of CMH Lahore Medical College

Institute of Dentistry

National University of Medical Sciences

Abdur Rehman Road Lahore Cantonment

Pakistan

Naauman Zaheer

School of Dental Sciences

PhD Scholar of Health Campus Kota Bharu

Universiti Sains Malaysia

16150 Kubang Kerian, Kelantan Darul Naim

Malaysia

Zainul Ahmad bin Rajion*

Craniofacial Medical Imaging Research Group

Faculty of School of Dental Sciences

Health Campus Kota Bharu

Universiti Sains Malaysia

16150 Kubang Kerian, Kelantan Darul Naim

Malaysia

Maliha Shahbaz

Oral Biology Department

Faculty of Rashid Latif Dental College

35 Km Ferozepur Road, Lahore

Pakistan

Usman Zaheer

Department of Orthodontics

Faculty of Lahore Medical and Dental College

P.O. Box B440, Askari 10 New Airport Road Lahore

Pakistan

Muhammad Qasim Saeed

Dean of Dentistry

Institute of Dentistry

CMH Lahore Medical College

National University of Medical Sciences

Abdur Rehman Road Lahore Cantonment

Pakistan 
Noor Hayati Abdul Razak

Department in Oral \& Maxillofacial Surgery

Faculty of School of Dental Sciences

Health Campus Kota Bharu

Universiti Sains Malaysia

16150 Kubang Kerian, Kelantan Darul Naim Malaysia
*Corresponding author; email: zar5057@gmail.com

Received: 30 May 2019

Accepted: 3 February 2020 